

\title{
OPORTO NEWSPAPERS AND THE CITY READERS. The construction of editorial and audiences identities
}

JORNAIS DO PORTO, PÚBLICOS

DA CIDADE. A construção da identidade editorial e das audiências

PERIÓDICOS DE OPORTO, PÚBLICOS DE LA CIUDAD. La construcción de la identidad editorial y las audiencias

DOI: http://dx.doi.org/10.12795/RiHC.2013.i01.04

Helena Lima

hllima@letras.up.pt; hldlima@gmail.com

Departamento de Jornalismo e Ciências da Comunicação da Faculdade de Letras da Universidade do Porto; Centro de Estudo em Media e Jornalismo (CIMJ)

Abstract: The three Oporto daily newspapers O Comércio do Porto, O Primeiro de Janeiro and Jornal de Notícias were founded during the XIX century and steadily grew in prestige and respect amongst the national Portuguese press. These papers began as local and ideological projects supported by political parties and a powerful commercial 
association but gradually evolved to more comprehensive newspapers with a wider range of lectors. Each particular profile was built through editorial policies which led to strategies of audience identification, underlined by the charisma of their owners and directors. The aim of this study is to identify the engagement processes with readers in their early days and the methodology will rely on sources such as newspapers contents and some other specialized publications. The key moments of evolution in Comércio, Janeiro and Notícias will be tracked by the adaptation to the modernization challenges according to reports, newspapers and some senior journalists' testimonies.

Keywords: Oporto daily newspapers, editorial profile, audience identification, Oporto's traditions and values, engagement process

Resumo: Os jornais portuenses $O$ Comércio do Porto, $O$ Primeiro de Janeiro e Jornal de Notícias, criados no século XIX, gradualmente estabeleceram-se como títulos nacionais de prestígio. Começaram como projetos ideológicos locais, apoiados em partidos políticos e uma poderosa associação comercial, mas com o tempo evoluíram para modelos noticiosos abrangentes, alargando o círculo de leitores. O perfil informativo de cada um construiu-se articulando-se com públicos-alvo e promovendo processos de identificação, potenciados pela ação de proprietários e diretores carismáticos. 0 objetivo deste estudo é identificar essas características editoriais específicas e os processos de fidelização de públicos na sua fase inicial, tendo como metodologia o estudo de conteúdo de jornais e publicações especilizadas. Os momentos chave de transformação serão identificados por jornais, relatórios e testumunhos de jornalistas.

Palavras-chave: diários portuenses, perfil editorial, valores e tradições portuenses, processos de identificação, fidelização de públicos

Resumo: Los periódicos de Oporto O Comércio do Porto, O Primeiro de Janeiro y Jornal de Notícias, surgieron en el siglo XIX y gradualmente se tornaron títulos nacionales de prestigio. Inicialmente dos de ellos eran proyectos ideológicos de partidos políticos locales y el tercero tenía el respaldo de la asociación comercial, pero con el tiempo fueron evolucionando hacia modelos de información más anchos, ampliando el círculo de lectores. El perfil informativo de cada uno se construyó en articulación con públicos específicos y a través de la promoción de procesos de identificación, reforzada por la acción de propietarios y directores carismáticos. El objetivo de este estudio es identificar estas características editoriales y procesos de conquista del público en sus primeras etapas, según una metodología basada en el contenido de los periódicos y publicaciones especializadas. Los momentos clave de la transformación serán identificados por los periódicos, informes y testimonios de periodistas.

Palabras clave: diarios de Oporto, perfil editorial, valores y tradiciones, procesos de identificación, manutención de públicos 


\section{Introduction and methodology}

The three Oporto daily newspapers O Comércio do Porto, O Primeiro de Janeiro and Jornal de Notícias were founded during the XIX century under a publicist purpose. They steadily grew in prestige and respect in the North Region and also eventually occupied a place in the national Portuguese press. Two of them (Janeiro and Notícias) were founded with an ideological frame and were supported by political parties, as for Comércio's launching it is related with the commercial association's interests. They all gradually evolved to more comprehensive newspapers, with diversified contents and a wider circulation. The transformation was partially obtained through the inclusion of local, national and international news and, increasingly, the daily factuality that builds a newspaper's agenda but keeping a focus on specific causes that involved Oporto interests.

This study aims to trace how the three Oporto newspapers achieved processes of identification by defining their founding matrixes and initial evolution. The diachronic approach will consist in the analysis of key moments of the transformation processes in order to understand how the initial models were transformed into more modern news projects. The methodology relies on historical sources such as newspapers contents and some other specialized publications. The evolution of Comércio, Janeiro and Notícias into a more informative shape is based on newspapers contents and for recent periods by the testimonies of senior journalists that began their careers during the 60 's of the 20th century. There is no data for circulation and consumption of the Portuguese press until the late years of the dictatorship and even those are very inaccurate. Reliable data on circulation was only available when the Portuguese association for circulation (APCT) was founded, in 1986 (LIMA, 2008). Therefore, the processes of the readers' conquest can only be deduced by the contents and writing style of each newspaper. The study of key moments in newspapers, scarce bibliography and journalists' statements aim to outline the three different profiles, each of them considered as national newspapers with a focus on Oporto and the North Region, but with particular traces of identity with their readers.

\section{Context}

Three major newspapers are part of the heritage of the city of Porto. O Comércio do Porto, O Primeiro de Janeiro and Jornal de Notícias emerged during the nineteenth century and obeyed to the general characteristics of the national Portuguese press. But they also presented some specific traits that distinguish them from the general scenario, marked by an ideological model that prevailed in this period. In fact, the 
connection to the city and the region gradually gave these three daily papers the intrinsic features that endured as their brand image and added value. This bond assumed a main role in the consolidation of their position in terms of readers and in terms of editorial orientation. During the evolutionary process, these titles eventually would seek a journalism nationwide oriented, although they have never lost the identifying details that prevailed as the initial brand image.

Portuguese journalism registered a considerable increase during the second half of the $19^{\text {th }}$ century which was due to the consolidation of the liberal regime and the new political stability. The new titles were mainly political, defending particular factions but with a typical short life span, and the vast majority were published in Lisbon and Porto. Therefore, the main challenge for those who launched a new newspaper was whether it would succeed in terms of audience because the press reading was an exclusive habit rather of rich people or politicians. Alberto Bessa indicated as reasons for the low circulation in press the ideological character and also the sale price: "(...) None of these newspapers that I quoted was what is properly called popular because their sale prices did not allow them to spread among the people, and the circulation was limited to those who shared the political ideal of their editors." (BESSA, 1904:170)

The natural ground for newspapers was the city with all the routines that it involves and all the peculiar facts that provide the news that stirs the public's curiosity. It took a long time for the Portuguese press to shape to this model and the implementation of the news journalism, featuring the daily headlines that allured the buyers. In 1864, Eduardo Coelho launched the Diário de Notícias a newspaper supported by the ads and with no political purposes. But for some time, in Oporto as in Lisbon, newspapers prevailed as propaganda instruments and the diffusion areas were defined and limited to the political engagement and maintained by powerful sponsors. This trend was gradually dimmed by the inclusion of news stories which turned traditional newspapers in a more attractive shape to a broader audience.

\section{From the ideological matrix towards a news model}

Despite differences in age, O Comércio do Porto, O Primeiro de Janeiro and Jornal de Notícias were all founded according to the traditional trend and the property structure described above. Only in time, the changes occurred in the companies allowed the gradual transformation that would lead to a popular information profile, eventually acquired by Oporto daily papers. 


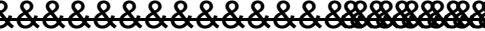


The reorganization of the layout led to a better distribution of the printing space. The daily edition had four pages and a cover story in the first page, and below a serial. The second and third page had a mix of subjects: news from abroad, usually taken from other newspapers, the pricing and movement of boats cargo at the river Douro's harbor. The last page had short news and announcements, some with small engravings. It was a blur of plain text, with scattered small graphics separators. This blur aspect tended to soften with the graphical improvements. With more space to publish, the separation between the news became more evident by the use of different types or by spacing. Gradually, and in parallel with these main subjects, Comércio became closer to a news model by the inclusion of diverse subjects and lighter news. However, the economic matters prevailed and other subjects were often copied from other national or international newspapers. Oporto and the North Region remained as central concern. The variety increased with the collaboration of correspondents from several Portuguese cities and the column Correio de Lisboa, mostly referring to the government measures. The column Telegrapho included financial news and international news were given by the Havas news agency and a net of international correspondents in Europe and Brazil. By the end of the century some special daily editions reorganized the news according to subjects, in an anticipation of the editorial sections.

After a complicated process of inheritance the Comércio became Bento de Sousa Carqueja Júnior's property who became the real mentor of its modernization in the early $20^{\text {th }}$ century. During this period the newspaper suffered many improvements and created some special editions such as the Comércio llustrado (1893), which included drawings of some of the best Portuguese artists; and the monthly Comércio Mensal (1915), largely composed with news from the Weekly Times. In 1903 Bento Carqueja launched $O$ Lavrador directed to the rural public but also associated to a plan of mobile schools that aimed to combat the heavy analphabetism that prevailed in the inner Center and North regions. The expansion of Comércio in terms of quality and audiences was also patent by the evening edition created in 1922 that included the daily news from Lisbon. Accordingly, new headquarters were built in the most strategic area of the city, at Avenida dos Aliados.

Bento Carqueja died in 1935 and his son-in-law Fortunato Seara Cardoso became the new director. The new phase of Comércio was also marked by the restrictions imposed by the dictatorship that led to a gradual decline of its standards in terms of quality of writing and the newsroom dynamics. Salazar's policy for printing was also very strict since he didn't allow more than 12 pages daily per week. As a result, most dailies had daily editions of 8 pages and the Sunday editions would include more pages, in order to ensure the ads. Apart from the censorship effects in terms of news, there were no renovation measures and editorial orientation only changed by the sale of most of Comércio's property to the Quina Group in 1973. 


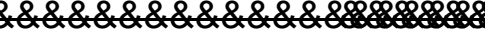


news reports. The sections were also modified. The international section was diversified and with more space. Lighter and humorous subjects were added like Correio da Moda or the Gazettilha. In the beginning of the 20th century O Primeiro de Janeiro had a great focus on information and reports, different sections and a group of correspondents from several Portuguese cities. It was proud of the serious tone kept in all matters and this reputation lasted in time. Janeiro did quality journalism:

"[The fait-divers] were treated with circumspect language, and sobriety marked its style. Around 1900, Janeiro, had a varied, attractive and short reading, (...). However it never gave emphasis to crimes or other human miseries. During this period, if someone compared the Lisbon newspapers to Janeiro, he would say that the latter was from another country, so silent and curt in reports of murders and robberies, scenes of jealousy or suicides, themes that other newspapers treated in detail, in the most repugnant way." (MARTINS, 1941: 50)

During the first decades of the 20th century Janeiro's life was never easy. It kept the political engagement and it was the only Oporto newspaper supporting the republican revolution, in 1910. In fact, the news of the revolution was given only by Janeiro, because the telegraph communications were controlled by the royalists. On January 6 , under the headlines "Communications with the capital are still cut", this daily gave some reports about the events occurred in Lisbon and also gave news of the instability felt in Oporto military quarters. That same day, Janeiro launched a special evening edition with the proclamation of the republic and in the following days this subject was profusely treated in a ton of joy: "Morning of radiant joy in the city. The news of the proclamation of the republic is accepted with enthusiastic rejoice", or "Bright and beautiful morning", or the "radiant dawn of redemption for justice that all from this newspaper awaited". The support to the new regime was stated during the following months and from then and forward $O$ Primeiro de Janeiro was the newspaper of the republican wing in Oporto and a mark for the opposition during the dictatorship. Therefore there was continuity on the political features that engaged its readers, kept during all the constitutional monarchy and enhanced by the commitment to the republican and democratic cause.

Nevertheless, the $1^{\text {st }}$ Republic was a period of great political, social and economic difficulties that were intensified by the Great War. The crises also affected the press due to the lack of paper, and in some days Janeiro's edition only had two pages or just wouldn't come out. In January, 1, 1919, the anniversary was celebrated under a grim mood: "Without pride, but with nobility, Primeiro de Janeiro celebrates its newspaper's $50^{\text {th }}$ anniversary". In the following days the somber tone would last enhanced by the news of a monarchic coup that endangered the republican regime. In this same year and due to heavy lack of resources Janeiro was sold to the "Lisbon Group". A new reform arrived and the new editorial guidance gave more importance 


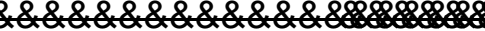




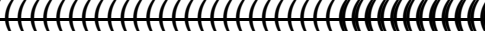




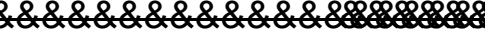


Church. The readers from the countryside and the clergy were part of the faithful public and expected this type of contents. This line of news gave Comércio a more traditional feature but not necessarily a total submission to the regime. In fact, the publication of a take about the seizing of the Portuguese navy motorboats by the Guinea partisans in the beginning of the colonial war, in spite of the express orders for not publishing, led to the suspension of this newspaper.

Another form of slight contradiction of Salazar's policy was related to the Church subjects. For instance, in 1967, Comércio made a large coverage of the Pope's visit to Fátima, and it was well known that Paul VI strongly condemned the dictatorship and the colonial war and this visit caused great unease in the circles of power and was seen as supportive for the non-conservative Catholics. In the same sense, in 1868, Comércio do Porto made a large interview to D. António Ferreira Gomes, the Bishop of Oporto known as a great opponent of Salazar's policy.

The slow loss of influence of Comércio was felt by Seara Cardoso and his son who, during the sixties, shared the direction of the newspaper. A few changes were tried, such as the hiring of some new reporters but with scarce effects. The big transformations occurred in the Portuguese press companies in this period implied substantial investments, which, in most cases, were provided by the acquisition of most of their ownership by the banks or the strong economic groups that controlled the Portuguese economy in that period (CORREIA, BAPTISTA, 2007; LIMA 2012). The investment that enabled the transformations of Comércio was brought by the Quina Group, a holding with several financial interests and owner of a bank, Borges \& Irmão. They bought most of Comércio's property and provided the loan to finance the modernization of the newspaper, during the early 70's. Transformations were made in the equipment and the printing process and a new crew of journalists was hired in order to renovate the newsroom. A new dynamism could be seen in the news by the inclusion of diverse subjects such as more sports, news concerning some of the Quina's interests and soft news like beauty contests and entertainment. The results of this transformation can't be assessed, due to the revolution of 1974.

During the dictatorship, Primeiro de Janeiro kept the label of being the daily of Oporto of republican-wing. In spite of the censorship, one of the ways found to show some defiance was a very complete coverage of Spanish civil war. The framing of the reports was in favour of left-wing forces and Janeiro gave detailed news of the combats, supported by pictures and maps that made the front pages' headlines. But the attitudes of rebellion were severely punished and, therefore, Janeiro had to accommodate just as the other newspapers. Nevertheless, the republican tradition was achieved by the inclusion of important chronicle authors that were against the 
(5) 


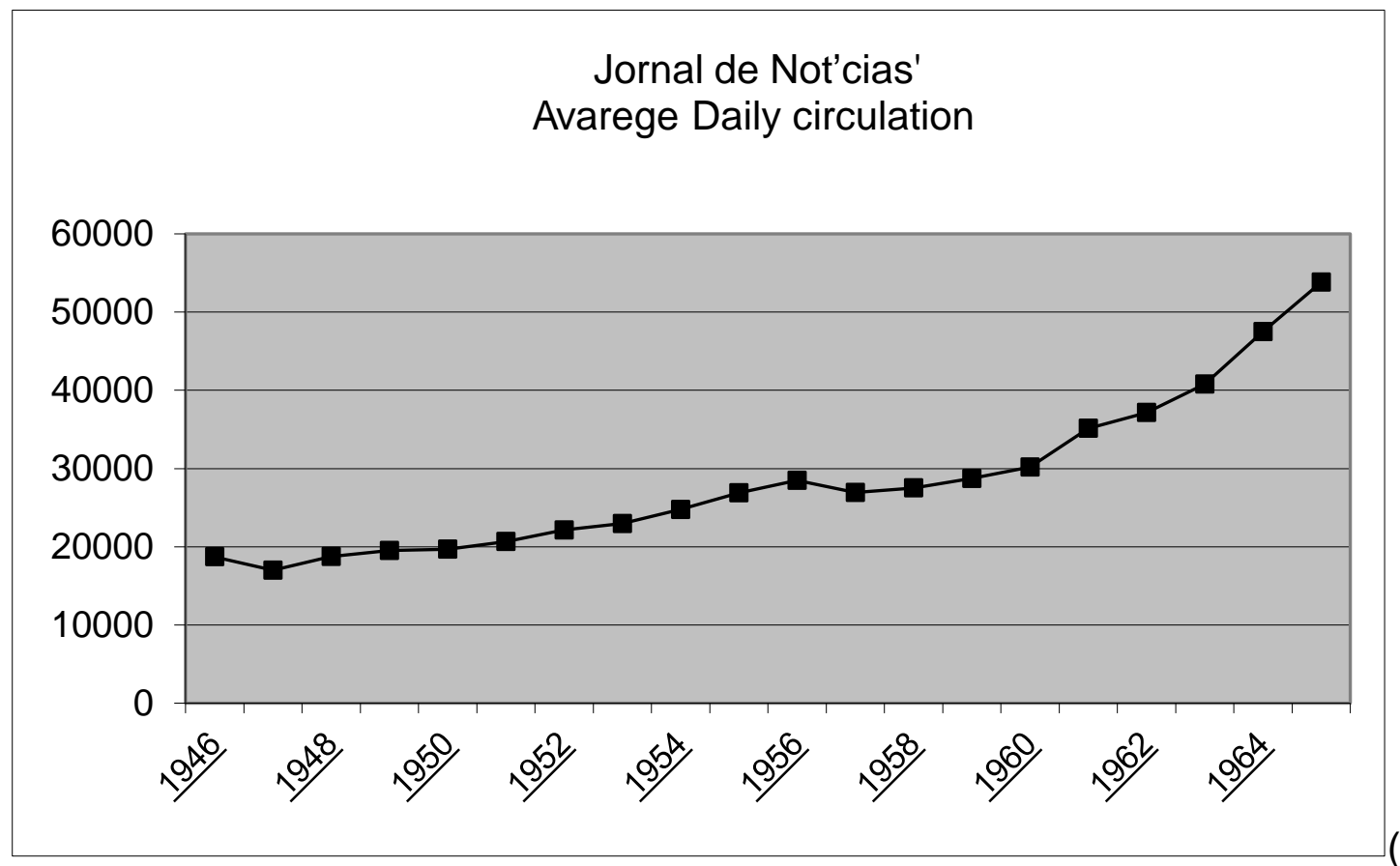


effects of the new guidance were reflected in the increase of circulation and, therefore, results in advertising. The daily was able to adjust to changing without disruptions. The hiring of new journalists in 1971 opened the doors to "Young people with academic training. We were greeted with suspicion and I must say with some aggressiveness." as Manuel António Pina referred. Despite the initial negative reception and some jealousy, the newsroom eventually integrated the newcomers and the modernization was operated without profound disturbances. Jornal de Notícias reassumed the emphasis on issues closer to the readers. It was also the first Oporto morning paper to be organized in sections. The reorganization of the printing space was directly linked to a greater number and diversity of news. However, the sinister role played by the censors acted as a hindrance in the intent of changing the newspaper.

The strict management and the rigor catapulted Notícias to the top of circulation. The public was also allured by the sports section. The coverage of the Oporto football teams and cycling tours became very important in this process of gaining the readers fidelity. Apart from sports, the tie between Notícias and the city was established in other several ways. The newspaper had a remarkable network of sources that was built thanks to the perseverance of the editor in chief Manuel Ramos, that never disregarded the phone calls from the public. Sometimes people called asking questions about an event and a reporter was always sent to the archives to seek facts, which permitted clarification but also would create a bond with the public. This interaction also worked the other way around and when some incident occurred in town the anonymous public called Jornal de Notícias and not the other dailies. Freitas Cruz confirms these interactions "In Notícias, we looked for the news and because of that, news came to us. There was a bond between the newspaper and the people". And this bond was straightened by the publication of small news that intended to draw attention to small problems that needed to be solved. In many cases people attended to the newspaper to complain and not to the authorities because they believed that the daily had the capacity to put things right. All this made Jornal de Notícias a very popular daily paper.

The fait-divers, the sports and the emotional writing were complemented by a colorful layout, in a very different style from the competition. Manuel Pina accepted the characterization of the competitors that scornfully characterized Notícias as the maids and the troopers' newspaper. It was indeed a popular newspaper and yet its journalists had a great pride in it, reflected in the words of Manuel Pina: "It always had this reputation of a popular newspaper, a newspaper poorly done. But nobody made a sloppy newspaper as well as we did." Some of these features have survived the upheavals of April 25, 1974, and have been instilled in successive generations of journalists who have been integrating the newsroom. The concept, along with the 
editorial guidance, prevailed and made Jornal de Notícias one of the largest national newspapers until the present time.

\section{Conclusions}

The three major Oporto newspapers started their publishing in the tradition of the nineteenth-century Portuguese press, ideological and educational in nature, and supported by political parties and the commercial association. This model evolved towards a more comprehensive news purpose according to a progressive transformation of contents and the gradual conquest of readers. This was achieved through loyalty strategies that were common to daily news, but also by a targeting to particular audiences that can only be inferred by the subjects treated by each newspaper, considering the impossibility of audience's studies for that period. These identification processes were achieved through specific policies, but they all included news concerning Oporto and the North region.

Gradually, they all opted by a wider range of subjects and became more comprehensive and with lighter contents. Still, Comércio, Janeiro and Notícias constructed particular audiences according to each particular profile. Comércio opted for a very careful editorial guidance, that can be considered as a quality paper, due to the subjects and quality of writing, educational purposes and graphic image. Janeiro also kept a serious tone in the news coverage and remained politically engaged and this feature assured a particular range of readers and that prevailed even during Salazar's dictatorship. Notícias also constructed a particular audience due to a much more popular approach that can be traced by the inclusion of more emotional news and framing, as well as a lighter writing style that were combined by a more gaudy graphic layout.

Each particular style and success were also linked to their leaders: Bento Carqueija, Gaspar Baltar and Anibal Moraes, but also Seara Cardoso, Pinto de Azevedo and Pacheco de Miranda. These personalities, through their dedication and personal visions carried forward the transformations in key moments of these newspapers history. In the $20^{\text {th }}$ century, and due the difficulties imposed by the dictatorship, the news contents were constrained which had heavy consequences. The modernization of the companies and the newsmaking processes were delayed until the late sixties, at least in Comércio and Notícias. In spite of these difficulties, some of the initial identity features were preserved and integrated into more modern and appealing models. 


\section{References}

ALVES, JORGE FERNANDES (2003) O Porto oitocentista: a cidade e os espaços industriais. In Separata de Arquitectando Espaços: da Natureza à Metapólis. Porto: Faculdade de Letras

- (1993) Analfabetismo e emigração: o caso do distrito do Porto no século XIX. In Revista da Faculdade de Letras: História. Porto: Faculdade de Letras, pp. 271-287

BALTAR, GASPAR FERREIRA (1934) À hora do Chã. Porto, Livraria Lello,

BASTO, A. MAGALHÃES (1939) Três fases do jornalismo portuense. Porto, Editora Maranus

BESSA, ALBERTO (1904) O jornalismo. Lisboa: Viúva Tavares Cardoso

CABRERA, ANA (2006) Marcello Caetano: poder e imprensa. Lisboa: Livros Horizonte.

CORREIA, FERNANDO (2006) Anos 60: um período de viragem no jornalismo português. In Media \& Jornalismo, O Jornalismo e a História. Coimbra: Minerva Coimbra, pp. 23-39

CORREIA, FERNANDO, BAPTISTA, CARLA (2007), Jornalistas: do Ofício à Profissão. Lisboa, Editorial Caminho

CUNHA, ALFREDO (1941) Elementos para a história da imprensa periódica portuguesa (1641-1821). Lisboa, Academia de Ciências de Lisboa

FORTE, ISABEL (2000) A censura de Salazar no Jornal de Notícias: da actuação da Comissão de Censura do Porto no Jornal de Notícias durante o governo de António Oliveira Salazar. Coimbra: Minerva Coimbra. (Comunicação)

GOMES, LUÍS F. (1925) Os jornalistas do Porto e a sua Associação. Associação dos Jornalistas e Homens de Letras do Porto

HORTA, ANA Leitura de jornais: aspectos de uma prática minoritária. [Em linha]. In V Congresso Português de Sociologia: Sociedades Contemporâneas: Reflexividades e Acção: Atelier Comunicação: Actas. [Consultado em 2 de Agosto de 2007]. Disponível em: http://www.google.pt/search?hl=ptPT\&q=leitura+de+jornais\%3Aaspectos+de+u ma+pr\%C3\%A1tica+minorit\%C3\%A1ria\&btnG=Pesquisar\&meta=

LIMA, HELENA (2012). A imprensa Portuense e os desafios da modernização. Lisboa, Livros Horizonte, Col. Media e Jornalismo

- (2011), O Jornal de Notícias no Portugal Democrático: luta política, deriva editorial e processo de renovação e conquista de públicos in Jornais, Jornalista e 
Jornalismo - Séculos XIX e XX, dir. Ana Cabrera, Livros Horizonte, Lisboa, Col. Media e Jornalismo.

LIMA, HELENA LAURA DIAS DE (2008) Os Diários Portuenses e os Desafios da Actualidade na Imprensa: Tradições e Rupturas. [Doc. Policopiado]. Porto: [Ed. Do autor]. [tese de Doutoramento].

MESQUITA, MÁRIO (1987) Sistema industrial estratégico, comunicação/indústria dos media in JNICT - Previsão e Avaliação em Ciência e Tecnologia, JNICT/ Programa FAST, Lisboa

Pequena história de um grande jornal: "O Primeiro de Janeiro" desde a sua fundação até entrar no 75 ano de existência (1948), Porto, O Primeiro de Janeiro

PRIMEIRO DE JANEIRO (O) (1988) In Enciclopédia Luso-Brasileira de Cultura. Lisboa: Verbo. Vol. 15

SOUSA, FERNANDO DE (1988) Jornal de Notícias: a memória de um século (1888-1988). Porto: Empresa do Jornal de Noticias

SOUSA, JORGE PEDRO (cord.) (2010) O pensamento jornalístico Português: das origens a Abril de 1974. Covilhã, LabCom

TENGARRINHA, JOSÉ MANUEL (2006) Imprensa e opinião pública em Portugal. Coimbra, Minerva Coimbra

\section{Sources}

\section{Newspapers and Magazines:}

Comércio do Porto $(0)$

Jornal de Notícias

Primeiro de Janeiro (O)

Tripeiro (O). Porto: Associação Comercial do Porto. 1919-1936

\section{Reports:}

Edição Comemorativa do 75 Aniversário do Jornal de Notícias, 1963

Empresa O Primeiro de Janeiro. Relatório do Conselho de Administração, 1953

Informação, Cultura Popular, Turismo, Ed.: Gabinete Técnico da Secretaria de Estado da Informação e Turismo, 1970-1973

O Comércio do Porto ao completar 80 anos. Porto, O Comércio do Porto, 1934

Os Jornalistas do Porto e a sua Associação, 1925 